Urszula Drozdowska

Uniwersytet $w$ Bialymstoku

\title{
ODPOWIEDZIALNOŚĆ ODSZKODOWAWCZA ZA NIEZAWINIONE SKUTKI OBOWIAZZKOWYCH SZCZEPIEŃ OCHRONNYCH - UWAGI DE LEGE LATA I DE LEGE FERENDA
}

\section{Wprowadzenie}

W obowiązującym stanie prawnym możliwość dochodzenia roszczeń za szkody powstałe na skutek wykonania obowiązkowych szczepień ochronnych została istotnie ograniczona. Stało się tak na skutek nowelizacji Kodeksu Cywilnego z dnia 17 czerwca 2004 r., ${ }^{1}$ która sprawiła, iż zastosowanie normy słusznościowej określonej w art. $417^{2}$ k.c. wymaga wykazania nie tylko szczególnej postaci szkody, ${ }^{2}$ za wynagrodzeniem której przemawiają zasady słuszności, lecz także udowodnienia, iż szkoda ta powstała w związku z wykonywaniem władzy publicznej.

$\mathrm{Na}$ gruncie obowiązujących regulacji prawnych prowadzenie działalności leczniczej jest identyfikowane $\mathrm{z}$ wykonywaniem działalności gospodarczej przez podmioty, których status prawny z woli ustawodawcy ${ }^{3}$ nie różni się tak bardzo od statusu innych podmiotów prowadzących działalność gospodarczą regulowaną. ${ }^{4}$ Wykonywanie działalności leczniczej nie prowadzi zwykle do wytworzenia stosunków prawnych ze sfery imperium, w których jeden podmiot (pacjent) jest władczo

1 Ustawa z dnia 17 czerwca 2004 r. o zmianie ustawy Kodeks Cywilny oraz niektórych innych ustaw (Dz.U. z 2004 r. Nr 164, poz. 1692).

2 Szkodą podlegającą kompensacji jest wyłącznie szkoda na osobie polegająca na naruszeniu dóbr osobistych (życia, zdrowia, integralności cielesnej) bądź szkoda polegająca na utracie żywiciela. Szerzej o tym dalej.

3 Por. uregulowania ustawy z dnia 15 kwietnia 2011 r. o działalności leczniczej (Dz.U. Nr 112, poz. 654 ze zm.).

$4 \quad Z$ wyjątkiem samodzielnego publicznego zakładu opieki zdrowotnej (spzoz) oraz jednostek budżetowych tworzonych przez odpowiednich ministrów, co do zasady podmioty lecznicze są przedsiębiorcami prowadzącymi działalność gospodarczą regulowaną. Jednocześnie pozbawienie statusu „przedsiębiorcy” spzoz-ów (dominujących w polskim szpitalnictwie) nastąpiło wyłącznie na gruncie przepisów ustawy o działalności leczniczej. Spzoz-y nie straciły przymiotu „przedsiębiorcy” w rozumieniu innych ustaw, w szczególności ustawy z dnia 2 lipca 2004 r. o swobodzie działalności gospodarczej (Dz.U. z 2010 r. Nr 220, poz. 1447 ze zm.) oraz na gruncie k.c. Zob. szerzej A. Zemke-Górecka, (w:) T. Mróz (red.), Uwarunkowania systemu opieki zdrowotnej w Polsce. Aspekty prawne i socjologiczne, Białystok 2012, s. 154-169. 
podporządkowany drugiemu (podmiotowi leczniczemu). W wyroku Sądu Najwyższego z dnia 13 maja 2005 r. ${ }^{5}$ zostało wyrażone stanowisko, że spełniając zadania publiczne, a do takich należy opieka zdrowotna wykonywana ze środków publicznych, zakłady opieki zdrowotnej nie stają się organami władzy, gdyż nie kształtują w drodze przymusu sytuacji prawnej pacjentów. Słusznie przyjmuje się, iż aktywność podmiotów leczniczych mieści się generalnie w tzw. sferze dominium, która związana jest $\mathrm{z}$ typową działalnością gospodarczą. ${ }^{6} \mathrm{~W}$ związku $\mathrm{z}$ tym $\mathrm{w}$ razie wyrządzenia szkody pacjentowi zastosowanie znajdują przepisy odnoszące się do ogólnych reguł odpowiedzialności deliktowej, tj. art. 415, art. 416, ewentualnie art. 430 k.c. ${ }^{7}$ We wszystkich wymienionych przypadkach konieczne staje się udowodnienie winy, bądź to w postaci winy organu, winy podwładnego lub tzw. winy organizacyjnej (ewentualnie anonimowej). ${ }^{8}$

W literaturze prawa medycznego wskazano jednak na wyjątkowe sytuacje, gdy w działalności podmiotu leczniczego pojawia się element władczy. ${ }^{9}$ Oprócz sytuacji przymusu leczenia w sferze psychiatrii pojawiła się propozycja, aby w podobny sposób potraktować poddanie pacjenta obowiązkowym szczepieniom ochronnym. ${ }^{10}$

Warto tu wskazać, iż obowiązkowe szczepienia ochronne nie różnią się od innych interwencji medycznych, jeśli idzie o kwestie związane z wyrażeniem na nie dobrowolnej zgody. ${ }^{11}$ Kwestia stosowania administracyjnego przymusu ma miejsce dopiero w razie nieuzasadnionej odmowy poddania się temu zabiegowi. Prawidłowo udzielona zgoda powoduje zatem przewidziane prawem skutki; przejście ryzyka związanego z zabiegiem z lekarza (podmiotu leczniczego) na pacjenta, a tym samym uwolnienie się od odpowiedzialności za niezawinione, uboczne skutki interwencji medycznej. Propozycja zatem objęcia przypadku powstania niezawinionych szkód poszczepiennych odpowiedzialnością na zasadach słuszności wiązana nie tyle $\mathrm{z}$ władczym charakterem relacji pacjenta z podmiotem leczniczym (przyjęcie koncepcji uświadomionej zgody na to nie pozwala), ile z obowiązkowym charakterem

Sygn. I CK 662/04, OSP 2009, nr 12, poz. 134.

Zob. zwłaszcza K. Bączyk-Rozwadowska, Odpowiedzialność cywilna za szkody wyrządzone przy leczeniu, Toruń 2013, s. 182 i.

Stanowisko to zostało potwierdzone w orzecznictwie SN, zob. wyrok SN z dnia 13 grudnia 2007 r., I CSK 384/07, OSP 2009, nr 2, poz. 20; wyrok SN z dnia 13 maja 2005 r., I CK 662/04, OSP 2009, nr 12, poz. 134 z glosą M. Nesterowicza.

Zob. M. Nesterowicz, Prawo medyczne. Komentarze i glosy do orzeczeń sądowych, Warszawa 2012, s. 61-95. Idem, Prawo medyczne, wyd. VIII, Toruń 2007, s. 364; tenże, glosa do wyroku SN z dnia 13 maja 2005 r. (I CK 662/04), (w:) Prawo medyczne. Komentarze i glosy do orzeczeń sądowych, op. cit., s. 26-27.

10 M. Safjan, Odpowiedzialność odszkodowawcza władzy publicznej (po 1 września 2004 r.), Warszawa 2004, s. 81; E. Bagińska, (w:) R. Hauser, Z. Niewiadomski, A. Wróbel (red.), System Prawa Administracyjnego, t. 12: Odpowiedzialność odszkodowawcza w administracji, Warszawa 2010, s. 268; M. Nesterowicz, Odpowiedzialność cywilna publicznego zakładu opieki zdrowotnej za wyrządzoną szkodę w świetle kodeksu cywilnego i art. 77 ust. 1 Konstytucji RP, PiM 2004, nr 2, s. 58.

Przeciwne stanowisko zajął Wojewódzki Sąd Administracyjny w Białymstoku w wyroku z dnia 16 kwietnia 2013 r. (sygn. II Sa/Bk 18/13). Sąd ten mianowicie uznał, iż obowiązek rodziców poddania dziecka obowiązkowym szczepieniom jest w Polsce obowiązkiem prawnym, a zwolnić z tego obowiązku mogą jedynie konkretne przeciwwskazania lekarskie. W związku z tym - zdaniem sądu - w przypadku obowiązkowych szczepień ochronnych wyłączone jest uprawnienie pacjenta do wyrażenia zgody na udzielenie określonych świadczeń zdrowotnych lub odmowy takiej zgody. 
szczepień. Właśnie dlatego przypadek ewentualnej odpowiedzialności za niezawinione szkody poszczepienne jest godny rozważenia.

Zastosowanie normy słusznościowej określonej przepisem art. $417^{2}$ k.c. wymaga udowodnienia, iż zdarzenie, z którym łączymy odpowiedzialność (w tym wypadku wykonanie obowiązkowego szczepienia) jest zadaniem związanym z wykonywaniem władzy publicznej. Następnie należy wykazać, iż na skutek tego zdarzenia została wyrządzona szkoda na osobie, a z okoliczności sprawy wynika, iż zasądzenia odpowiedniego odszkodowania i zadośćuczynienia wymagają względy słuszności. Odrębnym problemem jest zagadnienie legitymacji procesowej biernej, a zatem wyjaśnienie, kto w sytuacji powstania niezawinionych szkód poszczepiennych powinien zostać pociągnięty do odpowiedzialności. Wskazane tu kwestie będą przedmiotem szczegółowych rozważań w dalszej części publikacji.

\section{Publiczny charakter szczepień obowiązkowych}

Obszar ochrony zdrowia charakteryzuje się występowaniem dwóch rodzajów instrumentów prawnych: prywatnoprawnych i publicznoprawnych. ${ }^{12}$ Głównym organizatorem i finansującym opiekę zdrowotną jest Narodowy Fundusz Zdrowia. On to na zasadach określonych ustawą z dnia 27 sierpnia 2004 r. o świadczeniach opieki zdrowotnej finansowanych ze środków publicznych ${ }^{13}$ zawiera umowy ze świadczeniodawcami, na podstawie których udzielane są tzw. świadczenia gwarantowane. ${ }^{14}$ Niewątpliwie umowa o udzielanie świadczeń opieki zdrowotnej jest instrumentem cywilnoprawnym. Sam ten fakt - objęcia umową cywilną kwestii związanych z udzielaniem świadczeń zdrowotnych, a zatem także związanych z wykonywaniem szczepień ochronnych - nie pozbawia jednak publicznego charakteru samego zadania, jakim jest zapewnienie ludności ochrony przed chorobami zakaźnymi i zakażeniami. Warto podkreślić, iż aby zapewnić ochronę należy poddać szczepieniu jak największą grupę osób. Takie postępowanie prowadzi bowiem do ograniczenia lub eliminacji przenoszenia się drobnoustrojów pomiędzy ludźmi. ${ }^{15}$

12 Charakter publicznoprawny wykazuje przede wszystkim stosunek prawny pomiędzy ubezpieczonym pacjentem a NFZ. Działania NFZ przybierają niewątpliwie charakter władczy w sprawach indywidualnych z zakresu ubezpieczeń zdrowotnych. Fundusz wydaje indywidualne decyzje administracyjne (art. 109 i 110 ustawy o świadczeniach opieki zdrowotnej). Wskazuje sie również na możliwą odpowiedzialność Funduszu w sferze imperium za wadliwą organizację i finansowanie świadczeń. Zob. szerzej U. Drozdowska, (w:) T. Mróz (red.), Uwarunkowania systemu opieki zdrowotnej, op. cit., s. 149 i n.

13 T. jedn. Dz.U. z 2008 r. Nr 164, poz. 1027 ze zm.

14 Por. art. 15 ustawy cyt. w poprzednim przepisie i wydane na jego podstawie liczne rozporządzenia Ministra Zdrowia, określające tzw. koszyk świadczeń gwarantowanych. Szczepienia ochronne należą do świadczeń gwarantowanych, finansowane są one z budżetu państwa, z części pozostającej do dyspozycji Ministra Zdrowia. zob. rozp. z dnia 18 kwietnia 2002 r. w sprawie trybu finansowania z budżetu państwa kosztów świadczeń udzielanych w związku z chorobami zakaźnymi i zakażeniami (Dz.U. Nr 63, poz. 577).

15 Wskazuje się, iż uodpornienie wysokiego odsetka osób - ponad 80-90\% gwarantuje zahamowanie krążenia drobnoustroju i ochronę osób nie tylko zaszczepionych, lecz również tych, które z jakichkolwiek powodów nie zostały zaszczepione. To właśnie zjawisko odporności zbiorowiskowej stanowi, zdaniem zwolenników szczepień, społeczne uzasadnienie obowiązku szczepień. Zob. http://szczepienia.pzh.gov.pl, dostęp w dniu 15.09.2014. 
Publicznego charakteru tego zadania nie powinna także przekreślać kwestia wykonywania go przez podmioty lecznicze o różnym statusie prawnym; zarówno publicznym (tak w przypadku szpitali pozostających samodzielnymi publicznymi zakładami opieki zdrowotnej), jak i prywatnym (tak w razie wykonywania szczepień w prywatnych gabinetach lekarzy rodzinnych). Zwłaszcza, iż na tle obowiązujących regulacji prawnych decydujące znaczenie dla przypisania odpowiedzialności ma kryterium funkcjonalne, tj. typ danej aktywności, a nie przynależność do struktur o charakterze publicznoprawnym. ${ }^{16}$

W literaturze prawa podkreśla się, iż ,wykonywanie władzy publicznej” polega na korzystaniu z uprawnień wobec obywatela, które są silniejsze od uprawnień zwykłych osób. ${ }^{17}$ Tak więc władztwo publiczne przejawia się w jednostronnym sposobie kształtowania stosunków prawnych (tak w przypadku powstawania klasycznych stosunków administracyjnoprawnych). Z wykonywaniem władzy publicznej mamy do czynienia także w sytuacji, gdy dochodzi do stwierdzenia praw i wolności innych osób lub w razie wywarcia skutku w sferze tych praw (w tym ostatnim wypadku zwykle chodzi o działania faktyczne ${ }^{18}$ ). W wyroku z dnia 11 września 2006 r. Trybunał Konstytucyjny stwierdził, że pojęcie działania władzy publicznej nie może ograniczać się do sfery wykonywania ściśle pojętego imperium (tj. jedynie władczego kształtowania pozycji jednostki) ${ }^{19}$ uznał, iż pod tym pojęciem należy rozumieć różnego rodzaju formy wykonywania zadań publicznych, nawet pozbawione elementu władczego, ale wpływające na pozycję prawną jednostki. ${ }^{20}$

Koncepcja szerokiego rozumienia sfery imperium widoczna jest w wyroku SN z dnia 7 marca 2013 r., ${ }^{21}$ gdzie uznano, iż Skarb Państwa może ponieść odpowiedzialność na zasadach słuszności za szkodę doznaną w następstwie zakażenia bakteryjnego przez żołnierza, który odbywając służbę zasadniczą, znalazł się w sferze władzy publicznej jednostki wojskowej. W tym wypadku pozycję prawną jednostki wyznaczały dwa czynniki ,przymusowości”; pierwszy związany z odbywaniem obowiązkowej służby wojskowej, drugi związany z poddaniem się obowiązkowym szczepieniom na terenie jednostki wojskowej. Na skutek podania szczepionki doszło do obniżenia odporności poszkodowanego, a w następstwie tego zarażenia go groźną

Konsekwentnie zatem ani źródło finansowania świadczenia zdrowotnego: świadczenie jest finansowane ze środków publicznych, ani daninowy charakter składki ubezpieczeniowej nie stanowią jeszcze o władczym charakterze gwarantowanych świadczeń opieki zdrowotnej.

17 Zob. szerzej E. Bagińska, (w:) R. Hauser, Z. Niewiadomski, A. Wróbel (red.), System Prawa Administracyjnego, op. cit., s. 244-245.

W literaturze wskazuje się, iż zakres czynności faktycznych będących przejawem imperium jest bardzo pojemny. Obejmuje zarówno niezarejestrowanie dokumentu wpływającego do urzędu, nienależytą ochronę współwięźniów czy przekroczenie uprawnień funkcjonariuszy służb mundurowych, zob. szerzej E. Bagińska, Odpowiedzialność odszkodowawcza za wykonywanie władzy publicznej, Warszawa 2006, s. 251.

19 Sygn. P 14/06, OTK - ZU 2006, nr 8, poz. 102, podobnie w wyroku z dnia 23 maja 2006 r., SK 51/05, OTK - ZU 2006, nr 5, poz. 58.

20 Stąd $w$ literaturze podnosi się problem szerokiego i wąskiego ujmowania pojęcia imperium, zob. m.in. A. Doliwa, Dychotomiczny charakter podmiotowości prawnej państwa (imperium i dominium), „Studia Prawnicze” 2002, nr 3, s. 41.

21 Sygn. II CSK 364/12, OSP 2014, nr 2, poz. 16 z glosą K. Bączyk-Rozwadowskiej i M. Nesterowicza. 
bakterią Neisseria meningitidis, która wywołała posocznicę meningokową powikłaną wstrząsem septycznym. Warto podkreślić, iż w stanie faktycznym tej sprawy ustalono inne przypadki zarażenia, nie było więc wątpliwości, iż do zarażenia doszło na terenie jednostki wojskowej. Sąd w uzasadnieniu podkreślił, iż zarówno fakt odbywania obowiązkowej służby wojskowej, jak i poddania się obowiązkowym szczepieniom, które spowodowały spadek odporności, a w dalszej kolejności zakażenie groźną chorobą zakaźną wskazuje na to, że poszkodowany znalazł się w stanie faktycznego i prawnego przymusu. Te okoliczności zatem przemawiały za przyjęciem odpowiedzialności w sferze imperium.

Z kolei w wyroku Sądu Apelacyjnego w Białymstoku z dnia 29 lutego 2008 r. ${ }^{22}$ sąd uznał, iż do sfery imperium nie należą czynności z zakresu opieki zdrowotnej (w tym wypadku chodziło o zabieg dentystyczny) podjęte wobec osoby odbywającej karę pozbawienia wolności. Warto wskazać, iż w stanie faktycznym sprawy więzień wywodził odpowiedzialność zakładu karnego z faktu zarażenia go wirusem żółtaczki typu C w związku z korzystaniem z opieki zdrowotnej na terenie zakładu. $\mathrm{W}$ tym przypadku sąd przyjął wąskie rozumienie sfery imperium, wychodząc z założenia, iż spełniając zadania publiczne, a do takich należy realizacja wyroków sądowych, zakłady karne nie stają się organami władzy w zakresie zapewnienia opieki zdrowotnej i odpowiednich warunków odbywania kary pozbawienia wolności. Nie kształtują w tym zakresie w drodze przymusu sytuacji prawnej jednostki i działają poza sferą imperium.

Jakkolwiek można zgodzić się z pierwszym członem prezentowanej tezy, iż zakłady karne nie stają się organami władzy publicznej w zakresie zapewnienia opieki zdrowotnej, to jednak nie można przyjąć, iż nie mają one obowiązku zapewnienia odpowiednich warunków odbywania kary pozbawienia wolności. Przeciwnie, to właśnie w tej sferze regulowanej szczegółowo przepisami możemy dopatrywać się władczego oddziaływania zakładu karnego na sytuację prawną jednostki. Po pierwsze, odbywający karę pozbawienia wolności nie ma możliwości wyboru lekarza i miejsca, w którym chciałby się leczyć, a po drugie nie ma wpływu na warunki sanitarne panujące w zakładzie, zarówno w gabinecie lekarskim, w sali więziennej, czy w innych pomieszczeniach, w których przebywa. W związku z tym można polemizować z drugą częścią tezy wyroku Sądu Apelacyjnego. ${ }^{23}$ Brak elementu imperium można byłoby ewentualnie uznać w przypadku szkody wyrządzonej w związku z popełnieniem błędu medycznego, jednakże nie w przypadku zakażenia

22 Sygn. IACA 613/07, OSAB 2008, z. 1, poz. 12.

23 Abstrahuję tutaj od kwestii prawidłowości rozstrzygnięcia sporu, w sprawie tej były bowiem poważne wątpliwości, co do źródła zakażenia poszkodowanego. Więzień wykonywał w trakcie pobytu w więzieniu tatuaże, samookaleczenia oraz inne praktyki, związane z przyjmowaniem narkotyków. W związku z tym sąd oddalił powództwo. Zob. uzasadnienie wyroku cyt. w przyp. poprzednim. 
więźnia chorobą zakaźną. W tej bowiem sytuacji wyraźnie widoczny jest element ,przymusowości”. ${ }^{24}$

$\mathrm{Na}$ tle przedstawionego tu orzecznictwa można postawić pytanie, czy wykonanie obowiązkowego szczepienia w warunkach wolnościowych jest zdarzeniem prawnym, które może być źródłem odpowiedzialności w sferze imperium.

Zgodnie z ustawą z dnia 5 grudnia 2008 r. o zapobieganiu oraz zwalczaniu zakażeń i chorób zakaźnych u ludzi ${ }^{25}$ osoby przebywające na terenie RP (dłużej niż trzy miesiące ${ }^{26}$ ) obowiązane są do poddawania się szczepieniom ochronnym (art. 5 tej ustawy). Przepis art. 17 ust. 9 ustawy o chorobach zakaźnych i zakażeniach stanowi, iż lekarz sprawujący profilaktyczną opiekę zdrowotną ma obowiązek powiadomić pacjenta lub inną osobę uprawnioną do wyrażenia zgody o obowiązku poddania się szczepieniom. Szczegółowe kwestie związane z wykazem chorób zakaźnych objętych obowiązkiem szczepień, osoby lub grupy osób zobowiązane do poddania się tym szczepieniom, a także kwalifikacje osób uprawnionych do przeprowadzania szczepień oraz zasady dotyczące prowadzenia dokumentacji medycznej i sprawozdawczości określone są w rozporządzeniu Ministra Zdrowia z dnia 18 sierpnia 2011 r. w sprawie obowiązkowych szczepień ochronnych. ${ }^{27}$ Warto wskazać, iż w myśl przepisów rozporządzenia każde szczepienie powinno poprzedzać lekarskie badanie kwalifikacyjne. Badanie takie w przypadku dzieci poniżej 6. roku życia powinno być przeprowadzone w obecności opiekuna prawnego lub opiekuna faktycznego. ${ }^{28} \mathrm{~W}$ odniesieniu do małoletnich pomiędzy 6. a 18. rokiem życia, lekarskie badanie kwalifikacyjne oraz obowiązkowe szczepienie można przeprowadzić bez obecności wskazanych wyżej opiekunów, ale po uzyskaniu ich pisemnej zgody i po udzieleniu im odpowiednich informacji na temat uwarunkowań zdrowotnych mogących stanowić przeciwwskazanie do szczepień ( $\$ 7$ ust. 2 cyt. rozp.). ${ }^{29}$

Por. E. Bagińska (w:) R. Hauser, Z. Niewiadomski, A. Wróbel (red.), System Prawa Administracyjnego, op. cit., s. 278.

25 Dz.U. z 2008 r. Nr 234, poz. 1570 ze zm. Dalej w skrócie ustawa o chorobach zakaźnych i zakażeniach.

26 Co wynika z treści art. 17 ust. 1a ustawy o chorobach zakaźnych i zakażeniach, który zobowiązuje osoby przebywające na terytorium RP poniżej tego okresu do poddawania się jedynie tzw. szczepieniom poekspozycyjnym.

27 Dz.U. Nr 182, poz. 1086.

28 Przepis ten w świetle ustaw ustrojowych prawa medycznego wydaje się zbędny. Każdorazowo bowiem lekarz powinien uzyskać zgodę na badanie małoletniego od jego opiekuna prawnego lub opiekuna faktycznego, w związku z tym obecność tych osób jest niezbędna; zob. art. 17 ust. 2 ustawy z dnia 6 listopada 2008 r. o prawach pacjenta i Rzeczniku Praw Pacjenta (Dz.U. z 2009 r. Nr 52, poz. 417 ze zm.). Dalej ustawa o prawach pacjenta.

29 Na marginesie prowadzonych rozważań wskazać należy, iż rozwiązanie to może budzić wątpliwości z perspektywy innych przepisów z zakresu prawa medycznego (por. art. 15 i n. ustawy o prawach pacjenta oraz art. 32 i n. ustawy z dnia 5 grudnia 1996 r. o zawodach lekarza i lekarza dentysty (t. jedn. Dz.U. z 2011 r. Nr 277, poz. 1634 ze zm.). Z postanowień cytowanego rozp. wynika, iż opiekun prawny (opiekun faktyczny) może wyrazić zgodę na badanie kwalifikacyjne i szczepienie niejako jednocześnie; tymczasem dopiero badanie kwalifikacyjne dostarcza informacji, czy nie ma przeciwwskazań do szczepienia. W przypadku jednoczesnego wyrażenia zgody na obie procedury medyczne zgoda na szczepienie nie miałaby charakteru zgody uświadomionej i jako taka pozbawiona byłaby mocy prawnej. Następnie, przepisy rozporządzenia zrównują sytuację prawną opiekuna prawnego i opiekuna faktycznego. Tymczasem opiekun faktyczny może wyrazić zgodę jedynie na badanie kwalifikacyjne, nie może zaś wyrazić zgody zastępczej na interwencję o podwyższonym ryzyku, a do takich należy szczepienie. Wreszcie, analizowane rozp. nie uwzględnia istnienia zgody równoległej, która zakłada, iż po ukończeniu przez dziecko 16. roku życia ma ono prawo także wyrazić zgodę (lub sprzeciw) w przedmiocie szczepienia. 
Analizowane tu regulacje niewątpliwie potwierdzają konieczność wyrażenia poinformowanej zgody na szczepienie, w związku z tym nie można zgodzić się $\mathrm{z}$ prezentowaną $\mathrm{w}$ niektórych orzeczeniach sądów administracyjnych tezą, iż obowiązkowy charakter szczepień przekreśla prawo do wyrażenia zgody. ${ }^{30}$ Obowiązkowy charakter szczepień nie oznacza, iż pacjent staje się osobą bezwolną. Lekarz powinien przekonać pacjenta/opiekuna prawnego do tej metody profilaktyki, jeśli uznaje ją za bezpieczną i zgodną z zasadami wiedzy medycznej. Warto podkreślić, iż przymusowość szczepienia pojawia się dopiero w razie nieuzasadnionej odmowy pacjenta i/lub opiekuna prawnego i dopiero wtedy można twierdzić, iż mamy do czynienia z wyjątkiem od prawa do wyrażenia zgody. ${ }^{31}$ Należy też wskazać, iż przepisy cytowanego rozporządzenia dają podstawy do długotrwałego odroczenia obowiązku szczepienia, co wymaga odnotowania w dokumentacji medycznej ( $\$ 8$ rozp.). Jest to kwestia istotna z punktu widzenia rodziców dzieci, którzy są przeciwnikami tzw. „sztucznego" uodpornienia. ${ }^{32}$ Sprzeciw opiekuna prawnego, jeśli jest uzasadniony medycznie i poparty stanowiskiem lekarza może zatem prowadzić do legalnego zaniechania wykonania szczepienia obowiązkowego. W razie jednak nieuzasadnionej odmowy ustawodawca wprowadza środki prawne w postaci tzw. przymusu pośredniego i bezpośredniego.

Jak wskazuje M. Świderska przymus pośredni występuje wówczas, gdy przepis prawa zastrzega sankcje, np. karne lub administracyjne na wypadek odmowy zgody na zabiegi medyczne, co jednak nie stanowi podstawy prawnej dla przymusu fizycznego (bezpośredniego). ${ }^{33} \mathrm{Na}$ gruncie ustawy o chorobach zakaźnych i zakażeniach z przymusem bezpośrednim mamy do czynienia tylko w jednym przypadku. Zgodnie $z$ art. 36 ustawy wobec osoby, która nie poddaje się obowiązkowi szczepień, a u której podejrzewa się lub rozpoznano chorobę szczególnie niebezpieczną i wysoce zakaźną, stanowiącą bezpośrednie zagrożenie dla zdrowia lub życia innych osób może być zastosowany środek przymusu bezpośredniego polegający na przytrzymywaniu, unieruchomieniu lub przymusowym podaniu leków (tj. szczepionki). Ten rodzaj przymusu, co warto podkreślić, może być więc stosowany w sytuacjach zupełnie wyjątkowych, określonych w cytowanym przepisie.

30 Tak w uzasadnieniu wyroku WSA w Białymstoku z dnia 16 kwietnia 2013 r. (sygn. II Sa/Bk 18/13), http://orzeczenia.nsa.gov.pl

31 Wyjątki od zasady wyrażania zgody na leczenia w demokratycznym państwie prawnym muszą wynikać z przepisów ustawy (por. art. 31 ust. 3 Konstytucji RP). Zob. R. Kubiak, Odpowiedzialność prawna lekarza za szczepienie bez zgody lub za ciężkie, niepożądane odczyny poszczepienne, „Medycyna Praktyczna” 2012, nr 2, s. 88-92.

Liczba osób sprzeciwiających się obowiązkowym szczepieniom ochronnym w Polsce rośnie, przede wszystkim z racji wzrostu niepożądanych odczynów poszczepiennych, a także chorób, których występowanie rodzice łączą ze szczepieniem (jak np. autyzm). Jakkolwiek nie ma na to przekonywujących dowodów naukowych, część środowiska medycznego postuluje, aby szczepienia (zwłaszcza szczepionkami skojarzonymi) ograniczyć ze względu na konieczność kształcenia naturalnej odporności u dzieci. Por. argumenty zwolenników i przeciwników szczepień przedstawione przez P. Stanisławskiego, Dobrodziejstwo czy zło konieczne?, „Magazyn Integracja” 2008, nr 1, wyd. elektroniczne, http://www.niepelnosprawni.pl/ledge/, dostęp: 19.09.2014 r. M. Świderska, Zgoda pacjenta na zabieg medyczny, Toruń 2007, s. 248. 
Wobec osoby, która nie poddaje się szczepieniu, ewentualnie wobec jej opiekuna prawnego, który jest uprawniony do wyrażenia zgody zastępczej zdecydowanie częściej stosowane są inne, pośrednie instrumenty nacisku. O fakcie uchylania się od obowiązku poddania się szczepieniu lekarz jest zobowiązany zawiadomić właściwego państwowego, powiatowego inspektora sanitarnego. Zgodnie z art. 33 ust. 1 ustawy o chorobach zakaźnych i zakażeniach w przypadku podejrzenia lub rozpoznania zakażenia lub choroby zakaźnej inspektor może w drodze decyzji nakazać danej osobie poddanie sie obowiązkom określonym w art. 5 ust. 1 tej ustawy, a zatem także szczepieniu. Cytowany przepis dotyczy osób podejrzanych lub takich, u których stwierdzono zakażenie lub chorobę zakaźną, nie ma więc zastosowania w sytuacji odmowy wykonania profilaktycznych szczepień ochronnych. W przypadku zatem małoletnich podstawą stosowania przymusu administracyjnego wobec ich opiekunów prawnych są bezpośrednio przepisy ustawy z dnia 17 czerwca 1966 r. o postępowaniu egzekucyjnym $\mathrm{w}$ administracji. ${ }^{34}$ Procedurę rozpoczyna upomnienie informujące o konieczności zaszczepienia, a wypadku niewypełnienia tego obowiązku o charakterze niepieniężnym organ informuje, iż zostanie nałożona grzywna. ${ }^{35}$ Grzywna w celu przymuszenia ma na celu nakłonienie do wykonania obowiązku. Jeżeli jednokrotne zastosowanie grzywny nie odniesie skutku, może być ona nałożona ponownie w tej samej lub wyższej kwocie. Każdorazowo nałożona grzywna nie może jednak przekroczyć kwoty 10000 zł, zaś grzywny nakładane wielokrotnie nie mogą łącznie przekroczyć kwoty 50000 zł. W przypadku gdy wykonano obowiązek określony w tytule wykonawczym, nałożone grzywny w celu przymuszenia - na wniosek zobowiązanego - podlegają umorzeniu.

Obowiązek wykonywania szczepień ochronnych obwarowany jest także sankcją karną. Na podstawie art. 115 ust. 2 Kodeksu wykroczeń ten, kto sprawując pieczę nad osobą małoletnią lub bezradną, pomimo zastosowania środków egzekucji administracyjnej, nie poddaje jej określonemu obowiązkowemu szczepieniu ochronnemu podlega karze grzywny do 1500 zł lub karze nagany.

Objęcie sferą imperium przypadków szkód wyrządzonych przez szczepienia obowiązkowe w świetle powyższych uregulowań nie powinno budzić wątpliwości. Państwo w przepisach rangi ustawowej wprost przewiduje obowiązek poddania szczepieniom. Następnie zabezpiecza go administracyjnym przymusem bezpośrednim i pośrednim. Wreszcie przewiduje sankcje karne w przypadku nieuzasadnionej odmowy. Aktywność zatem przedstawicieli ochrony zdrowia, którym przekazano pieniom zabezpieczone jest przymusem administracyjnym oraz odpowiedzialnością regulowaną przepisami ustawy z dnia 20 maja 1971 r. Kodeks wykroczeń (t. jedn. Dz.U. z 2010 r. Nr 46, poz. 275 ze zm.), to obowiązek ten jako wynikający z przepisów prawa jest bezpośrednio wykonalny. Jego niewykonanie aktualizuje obowiązek wszczęcia postępowania egzekucyjnego. Nie ma więc potrzeby wydawania decyzji administracyjnej. Organem właściwym do prowadzenia egzekucji, jak wynika z orzecznictwa sądów administracyjnych jest wojewoda. Zob. wyrok NSA z dnia 1 sierpnia 2013 r., II OSK 745/12, a także wyrok WSA w Białymstoku z dnia 3 września 2013 r., II Sa/Bk 247/13. Orzeczenia wraz z uzasadnieniami są dostępne w Centralnej Bazie Orzeczeń Sądów Administracyjnych http://orzeczenia.nsa.gov.pl 
realizację zadań publicznych w tym zakresie mieści się sferze faktycznych działań imperialnych.

Analiza powyższych regulacji wskazuje także, iż w przypadku obowiązkowych szczepień ochronnych, jak i sposobu prowadzenia egzekucji w celu przymuszenia powinna być przestrzegana określona prawem procedura. Udowodnienie przez poszkodowanego naruszenia przepisów prawa pozwala przyjąć bezprawność zachowania. Wówczas możliwe jest zastosowanie ogólnych reguł odpowiedzialności (art. 417 k.c.). ${ }^{36}$

\section{Problematyka związku przyczynowego oraz szczególnej postaci szkody na tle normy słusznościowej określonej w art. $417^{2}$ k.c.}

W sprawach medycznych (nie tylko na tle art. $417^{2}$ k.c.) problematyczna staje się kwestia wykazania adekwatnego związku przyczynowego pomiędzy określonym zdarzeniem, z którym powód łączy odpowiedzialność a doznaną szkodą. Wynika to przede wszystkim z faktu, iż w przypadku szkód na osobie skutek w postaci rozstroju zdrowia lub uszkodzenia ciała jest pochodną wielu różnych czynników. Jak podkreślono w wyroku Sądu Apelacyjnego w Poznaniu z dnia 17 stycznia 2006 r., ${ }^{37}$ gdy chodzi o ustalenie przyczyny utraty lub pogorszenia zdrowia ludzkiego istnienie związku przyczynowego z reguły nie może być absolutnie pewne, toteż wystarczy ustalenie go z dużą dozą prawdopodobieństwa. W związku z powyższym sądy w szerokim zakresie stosują ułatwienia dowodowe w postaci określenia stopnia prawdopodobieństwa w relacji skutek - przyczyna, a także korzystają z domniemań faktycznych (art. 231 k.p.c.). ${ }^{38}$

W orzecznictwie dotyczącym dawnego art. 419 k.c. wprost dopuszczano rezygnację z obowiązku udowodnienia przyczynowości adekwatnej w rozumieniu art. $361 \S 1$ k.c. W sprawie dotyczącej poważnych konsekwencji obowiązkowego szczepienia ochronnego ${ }^{39}$ czytamy, iż nie chodzi o to, aby działanie funkcjonariusza państwowego zmierzało do wyrządzenia szkody, lecz o ustalenie, że bez tej czynności szkoda nie mogłaby powstać. Powódka zatem uchroniłaby się przed szkodą wywołaną poszczepiennym zapaleniem mózgu, gdyby zrezygnowała z zabiegu szczepie-

36 W sprawie zakończonej wyrokiem Sądu Apelacyjnego w Łodzi z dnia 30 listopada 2012 r. (I ACa 1140/12, LEX nr 1246730) małoletniemu wykonano szczepienie DiPer-Te + Polio po uprzednim zbadaniu przez lekarza, który nie stwierdził przeciwwskazań, pomimo iż dziecko było uprzednio chore i podawano mu antybiotyk. Po około 6 godzinach po szczepieniu rozpoczęła sie uogólniona infekcja i dziecko w stanie bardzo ciężkim zostało przewiezione do szpitala. Wystąpiło ciężkie, nieodwracalne uszkodzenie ośrodkowego układu nerwowego, które było w bezpośrednim związku czasowym z wykonanym w wieku 8 miesięcy szczepieniem ochronnym. Podstawą odpowiedzialności był w tym wypadku art. 417 § 1 k.c. w danym brzmieniu.

37 Sygn. IACA 1983/04, LEX nr 186503.

38 Zob. B. Janiszewska, Aktualne zagadnienia procesów lekarskich (przegląd orzecznictwa), PiM 2004, nr 1, s. 39 i n.; taż, Dowodzenie w procesach lekarskich, (domniemania faktyczne i dowód prima facie), PiM 2004, nr 2. Wyrok SN z dnia 5 września 1969 r., II CZ 223/69, LEX nr 6554. 
nia ochronnego przeciwko durowi brzusznemu i tężcowi. W wyroku z dnia 4 marca 2008 r. Sąd Najwyższy wprost stwierdził, iż dla spełnienia humanitarnego celu realizowanego przez art. 419 k.c. można odstąpić od wymagania, aby między szkodą a zachowaniem się istniał normalny związek przyczynowy i poprzestać na ustaleniu niekwalifikowanego powiązania kauzalnego. ${ }^{40}$

Jak się wydaje, ten kierunek interpretacji powinien zostać utrzymany także na gruncie obecnie obowiązującego art. $417^{2}$ k.c., pożądane jest to zwłaszcza w sprawach dotyczących szkód poszczepiennych. ${ }^{41}$ Jak wskazuje E. Bagińska trudności w przypadku szczepień polegają na tym, iż na rynku funkcjonują szczepionki różnych producentów (trudno zatem czasem dociec, szczepionka którego producenta wywołała określone powikłanie ${ }^{42}$ ), niektóre z nich są w czasie produkcji zanieczyszczone ,patogenami”, mogą więc spowodować atypową reakcję organizmu, zupełnie nie do przewidzenia, ${ }^{43}$ wreszcie mogą wywołać reakcję organizmu po dość długim czasie. ${ }^{44}$ To wszystko sprawia, że udowodnienie relacji kauzalnej staje się wyjątkowo skomplikowane, a po stronie poszkodowanych powstaje niepewność, co do wyniku sprawy. ${ }^{45}$

Analiza orzeczeń sądów apelacyjnych wskazuje, iż nawet zaistnienie poważnych szkód medycznych (np. ciężkiego, nieodwracalnego uszkodzenia ośrodkowego układu nerwowego skutkującego trwałym kalectwem) nie pozwala często stwierdzić związku przyczynowo-skutkowego pomiędzy szczepieniem a szkodą. W wyroku Sądu Apelacyjnego w Łodzi z dnia 30 listopada 2012 r. sąd wskazal, iż występowanie dodatkowych okoliczności pod postacią zaburzeń przebiegu ciąży i zaburzeń wzrastania płodu może stanowić o wystąpieniu czynników ryzyka powikłań poszczepiennych, trudnych do identyfikacji. Ponieważ jednak bezpośrednio po przyjęciu małoletniego powoda do szpitala lekarz stwierdził wystąpienie powikłań poszczepiennych, wpis ten (w dokumentacji medycznej) stał się przyczyną uznania przez sąd, iż pomiędzy wystąpieniem choroby a szczepieniem istnieje związek. ${ }^{46}$ Odmiennie sąd wypowiedział się w sprawie rozpatrywanej przez Sąd Apelacyjny w Poznaniu. ${ }^{47}$ Zdaniem sądu przyczyn porażenia mózgowego dziecka należało upatrywać $\mathrm{w}$ przedwczesnym porodzie i niedojrzałości oraz prawdopodobnie w utajnionym krwawieniu śródczaszkowym. Biegli wskazali, iż możliwe były dwie sytuacje;

Sygn. IV CSK 453/07, LEX nr 371407.

Zob. E. Bagińska, Odpowiedzialność deliktowa w razie niepewności związku przyczynowego, Toruń 2013, s. 39.

W przypadku ustalenia wadliwości szczepionki konkretnego producenta możliwe jest pozwanie go na podstawie przepisów o odpowiedzialności za wprowadzenie do obrotu produktu niebezpiecznego (art. $449^{1}$ i n. k.c.).

Przypadki te generalnie nie mieszczą się więc w warunkach przyczynowości normalnej/adekwatnej. Jakkolwiek SN w wyroku z dnia 7 marca 2013 r., II CSK 364/12 uznał, że atypowość, a nawet zupełna sporadyczność następstw nie pozbawia związku przyczynowego cechy adekwatności (cytuję: „normalność następstw nie jest bowiem pochodną ich typowości, lecz raczej kwestią zdatności konkretnej przyczyny do wywołania określonego rodzaju skutków"), tym niemniej klasyczne ujęcie adekwatnego związku przyczynowego zakłada odrzucenie skutków nietypowych i nienormalnych dla danego zdarzenia.

E. Bagińska, Odpowiedzialność deliktowa w razie niepewności związku przyczynowego, op. cit., s. 104.

Zob. wyrok SN z dnia 26 lipca 2012 r., II CSK 759/11, LEX nr 1218166.

Zob. wyrok SA w Łodzi z dnia 30 listopada 2012 r., I ACa 1140/12, LEX nr 1246730.

Wyrok SA w Poznaniu z dnia 22 stycznia 2013 r., I ACa 1160/12, LEX nr 1322020. 
porażenie mózgowe u powoda rozwijało się niezależnie od podania szczepionki (przed podaniem szczepionki chłopiec rozwijał się prawidłowo, ale zdaniem biegłych o niczym to nie świadczyło), ewentualnie podanie szczepionki mogło zadziałać jak ,mechanizm spustowy” i ujawnić objawy porażenia, które także ujawniłyby się z czasem. W efekcie powództwo oddalono.

W sprawach dotyczących wynagrodzenia szkód poszczepiennych pojawia się także wątek ryzyka, jakie bierze na siebie pacjent wyrażając zgodę na daną interwencję medyczną. W orzecznictwie dotyczącym dawnego art. 419 k.c. można spotkać pogląd, iż przepis art. 419 k.c. nie daje podstaw do żądania całkowitego lub częściowego naprawienia szkody przez Skarb Państwa, jeżeli rozstrój zdrowia mieści się w granicach ryzyka związanego z danym zabiegiem, tym bardziej gdy chory uprzedzony o istnieniu ryzyka, zgodził się na przeprowadzenie zabiegu. Żądanie odszkodowania w takich okolicznościach nie znajduje uzasadnienia w zasadach słuszności. ${ }^{48} \mathrm{~W}$ przypadku jednak szkód poszczepiennych, gdy ryzyko ich wystąpienia z samej już definicji jawi się jako wyjątkowe, nie może być mowy o uwolnieniu się od odpowiedzialności na tej tylko podstawie, iż pacjent/opiekun prawny został uprzedzony o ryzyku. Klasycznym przykładem w tego typu sprawach przyjęcia innego toku rozumowania jest wyrok SN z dnia 11 września 1968 r., ${ }^{49}$ w którego tezie czytamy: „Szczepienia ochronne zarządzane są w interesie całego społeczeństwa i każdego obywatela, a normalnie też nie powodują u osób szczepionych żadnego poważniejszego rozstroju zdrowia, jeżeli jednak wyjątkowo - z niewyjaśnionych dotychczas przez naukę i przez nikogo niezawinionych przyczyn - rozstrój taki nastąpił, powodując trwałe kalectwo, zasady współżycia społecznego przemawiają za zasądzeniem odszkodowania". Podobnie w wyroku z dnia 20 sierpnia 1968 r. ${ }^{50}$ sąd wskazał, iż względy słuszności z reguły przemawiają za naprawieniem przez Skarb Państwa szkody, jakiej osoba poddana przymusowemu szczepieniu dokonanemu przez uprawnionego funkcjonariusz państwowego doznała, w wypadku ciężkiego rozstroju zdrowia na skutek tego szczepienia, chociażby było ono przeprowadzone w sposób prawidłowy.

Analizowane przypadki mieszczą się z reguły w dyspozycji normy art. $417^{2}$ k.c., jeśli chodzi o zakres szkód podlegających rekompensacie. Szkodą tą - w myśl cytowanego przepisu - jest wyłącznie szkoda na osobie polegająca na naruszeniu dóbr osobistych (życia, zdrowia, integralności cielesnej) bądź szkoda polegająca na utracie żywiciela. Cytowane orzecznictwo nie pozostawia żadnych wątpliwości; szkody te mają charakter poważny, często nieodwracalny i pociągają za sobą negatywne skutki dla osób poszkodowanych i ich bliskich. W związku z tym za ich rekompensatą - zgodnie z brzmieniem art. $417^{2}$ k.c. - przemawiają względy słuszności.

48 Tak SN w wyroku z dnia 25 września 1969 r., II CR 353/69, OSNC 1970, nr 6, poz. 116.

49 Sygn. II CR 325/68, LEX nr 6390.

50 Sygn. II CR 310/68, OSNC 1969, nr 2, poz. 38 z glosą M. Sośniaka, OSP 1969, nr 3, poz. 67. 


\section{Kwestia legitymacji biernej}

Legitymowanym biernie w sprawie związanej z odpowiedzialnością za szkody poszczepienne najczęściej jest podmiot leczniczy, z którego działalnością łączymy szkodę. Powierzenie zadań z zakresu szczepień obowiązkowych wynika z mocy przepisów prawa (z przepisów cytowanej ustawy o chorobach zakaźnych i zakażeniach). Należy zatem uznać, iż mamy do czynienia z decyzją ustawodawcy o przyznaniu kompetencji. Odpowiedzialność wykonawcy władzy publicznej opiera się wówczas na art. $417 \S 1$ k.c., a w razie nieudowodnienia przesłanki bezprawności na art. $417^{2}$ k.c.

Rozwiązanie to może jednak budzić uzasadnione wątpliwości z perspektywy podmiotu leczniczego zobowiązanego do wypłaty odszkodowania/zadośćuczynienia. Skoro bowiem obowiązek poddania się szczepieniom narzucony jest odgórnie (pochodzi od władzy publicznej) i ma na celu ochronę społeczeństwa przed chorobami zakaźnymi, to powstaje pytanie, czy w sytuacji braku bezprawności państwo nie powinno przejąć ciężaru odpowiedzialności odszkodowawczej w razie powstania szkód poszczepiennych.

Idea słuszności, jak słusznie podkreśla J. Parchomiuk, nawiązuje do teorii równości wobec ciężarów publicznych. ${ }^{51}$ Odpowiedzialność aktualizuje się w przypadku podjęcia działania zgodnego $\mathrm{z}$ prawem $\mathrm{w}$ interesie publicznym, którego następstwem jest nieoczekiwany i niedający się przewidzieć uszczerbek w dobrach takich jak życie i zdrowie. Teoria ta ma zastosowanie w ograniczonych tylko sytuacjach, gdy krąg poszkodowanych jest nieliczny. Jeśli więc jednostka poniosła ten uszczerbek to słuszne jest, aby ciężar ten został przeniesiony poprzez odpowiedzialność odszkodowawczą przynajmniej w części na społeczeństwo, czerpiące korzyści z działania władzy publicznej. Wskazana wyżej teoria stała się podwaliną tworzenia tzw. funduszy kompenasacyjnych ${ }^{52}$ których celem jest nie tylko zapewnienie szybkiej i uproszczonej procedury uzyskania przez pacjenta rekompensaty, ale także uwolnienie producentów szczepionek i podmiotów leczniczych od nadmiernego ciężaru odpowiedzialności. ${ }^{53}$ Jak wskazuje E. Bagińska, przerzucenie ciężaru odpowiedzialności na władzę publiczną w rozwiniętych cywilizacyjnie systemach gwarantuje powszechny i stały dostęp do szczepień najnowszej generacji, a koszty

51 J. Parchomiuk, (w:) System Prawa Administracyjnego, R. Hauser, Z. Niewiadomski, A. Wróbel (red.), op. cit., s. 192.

52 Fundusz taki powstał np. na podstawie amerykańskiej ustawy federalnej z 1986 r. (The National Childhood Vaccine Injury Act of 1986), zob. szerzej E. Bagińska, Odpowiedzialnośc państwa za szkody medyczne w prawie amerykańskim, (w:) Hominum causa omne ius constitutum est. Ksiega Jubileuszowa ku czci Prof. Alicji Grześkowiak, Lublin 2006, s. 416-418, a także w wielu krajach europejskich, np. we Francji - już w latach 60-tych XX wieku ustawą z dnia 1 lipca 1964 r. (znowelizowaną 26 maja 1975 r.) wprowadzono model odpowiedzialności Państwa za szkody doznane w następstwie obowiązkowych szczepień ochronnych, od 1971 r. model odpowiedzialności za szkody wyrządzone przez szczepionki funkcjonuje także w Niemczech, a od 1979 r. - na mocy Vaccine Damage Payments Act of 1979 - w Wielkiej Brytanii, zob. szerzej K. Bączyk-Rozwadowska, Odpowiedzialność cywilna za szkody wyrządzone przy leczeniu, op. cit., s. 300 i n. 
odpowiedzialności wobec nielicznych poszkodowanych w ostatecznym rezultacie rozkładają się na całe społeczeństwo. ${ }^{54}$

W związku z powyższym (de lege ferenda) legitymowanym biernie powinien być Skarb Państwa. Uzasadnienie tej odpowiedzialności tkwi nie tylko we wskazanych wyżej argumentach natury słusznościowej i koniecznej w tym wypadku rekompensaty. Mechanizmy prawne powinny prowadzić do zachowania równowagi w relacjach podmiot leczniczy - pacjent. Brak tej równowagi prowadzi do zachowań niepożądanych. Rodzice małoletnich pacjentów skarżą się mianowicie, że wystąpienie reakcji poszczepiennej nie jest odnotowywane przez lekarzy rodzinnych w dokumentacji medycznej bądź też wskazują, iż powikłania tego typu - mimo odpowiednich regulacji prawnych ${ }^{55}$ - nie są zgłaszane odpowiednim instytucjom. Obawa więc przed ponoszeniem odpowiedzialności prowadzi do uprawiania tzw. medycyny defensywnej, co w tym przypadku oznacza ignorowanie objawów poszczepiennych u dzieci lub przypisywanie tym objawom innej etiologii.

\section{Wnioski}

Na gruncie omawianej problematyki dylemat, czy zdrowie jest dobrem indywidualnym czy dobrem publicznym jest rozstrzygany zdecydowanie w kierunku dobra publicznego ${ }^{56}$ Bezpośrednim celem szczepień jest poprawa zdrowia całej populacji. Pozytywne, ogólnospołeczne skutki szczepień przeważają nad indywidualnym uszczerbkiem. Przypadki niepożądanych szkód poszczepiennych nie są zbyt częste i w związku z tym korzyści płynące z obowiązkowych szczepień przesądzają o potrzebie ich utrzymania.

Swego czasu w orzecznictwie Sądu Najwyższego na tle dawnego art. 419 k.c. lansowane było tzw. kryterium celu, do którego zmierzał funkcjonariusz publiczny wykonując określone zadanie. Otóż w przypadku, gdy zachowanie funkcjonariusza państwowego, które wyrządziło szkodę nosiło znamiona działania wyłącznie lub przede wszystkim w interesie społecznym jako całości, uzasadnione było w świetle zasad współżycia społecznego wynagrodzenie szkody. Przyjmowano, iż skoro na poszkodowanym ciąży obowiązek podporządkowania się poleceniu funkcjonariusza, to nie mając możliwości uniknięcia szkody, ma on prawo domagać się jej rekompensaty. ${ }^{57}$ Przyjmując ten punkt widzenia w odniesieniu do obowiązkowych

\footnotetext{
$54 \quad$ Ibidem.

55 Zob. Rozp. Ministra Zdrowia z dnia 21 grudnia 2010 r. w sprawie niepożądanych odczynów poszczepiennych oraz kryteriów ich rozpoznania (Dz.U. Nr 254, poz. 1711).

56 Zob. I. Wrześniewska-Wal, A. Augustynowicz, Aspekty prawne obowiązkowych szczepień ochronnych u dzieci, „Pediatria Polska” 2013, nr 2, s. 120-126.

57 W doktrynie w odniesieniu do tak sprecyzowanego kryterium celu wskazywano, że zachowanie szkodzące funkcjonariusza mające na względzie interes społeczny zawsze przemawia na korzyść poszkodowanego. Jednakże brak takiego interesu nie powinien przesądzać o oddaleniu powództwa z art. 419 k.c., zwłaszcza gdy dany interes indywidualny poszkodowanego jest jednocześnie interesem społecznym. Tak w szczególności A. Śmieja, Związek przyczynowy i zasady współżycia społecznego w świetle art. 419 k.c., „Acta Uniwersitatis Wratislaviensis”
} 
szczepień ochronnych należy opowiedzieć się za możliwością dochodzenia roszczeń odszkodowawczych na podstawie art. $417^{2}$ k.c. De lege ferenda należałoby stworzyć - wzorem innych państw - system wynagradzania szkód poszczepiennych, ${ }^{58}$ który pozwoliłby poszkodowanym uniknąć długiej i kosztownej procedury sądowej.

Krańcowo odmiennym rozwiązaniem (ale w obecnej sytuacji chyba najuczciwszym wobec poszkodowanych pacjentów) byłaby zmiana polityki prozdrowotnej i przyjęcie w miejsce obowiązkowego systemu szczepień - systemu fakultatywnego. Idea, aby szczepienia w Polsce były całkowicie dobrowolne ma swoich licznych zwolenników. Nawet bowiem największe odszkodowanie czy zadośćuczynienie nie przywróci zdrowia tym, którzy go utracili.

1990, nr 1152, s. 325 i n. Ze względu na trudności ze ścisłym odgraniczeniem interesu indywidualnego od publicznego późniejsze orzecznictwo przyjęło, iż działanie funkcjonariusza mające na celu określony interes indywidualny nie przekreśla możliwości wykazania, iż naprawienia szkody wymagają względy słuszności.

58 Wprowadzony dnia 1 stycznia 2012 r. (nowelizacją ustawy o prawach pacjenta i Rzeczniku Praw Pacjenta, Dz.U. z 2011 r. Nr 113, poz. 660) nowy sposób kompensacji szkód medycznych przed Wojewódzką Komisją ds. orzekania o zdarzeniach medycznych nie ma zastosowania do niezawinionych szkód poszczepiennych. Indemnizacji podlegają jedynie skutki zachowań niezgodnych z aktualną wiedzą medyczną w zakresie (w tym wypadku) zastosowania produktu leczniczego (por. art. 67a i n. ustawy), a zatem bezprawne. Dodatkowo ten administracyjny model kompensacji szkód medycznych odnosi się wyłącznie do szpitali, tymczasem gros szczepień wykonywanych jest w gabinetach lekarzy rodzinnych. 
LIABILITY FOR DAMAGES FOR FAULTLESS EFFECTS OF OBLIGATORY VACCINATIONS - COMMENTS DE LEGE LATA AND DE LEGE FERENDA

The author discusses liability for damages for faultless effects of obligatory vaccinations. The legal basis of the responsibility may be the Article $417^{2}$ of the Polish Civil Code. The regulation requires to prove that fulfillment of the mandatory vaccination is a task bound up with the execution of public authority. Next it is necessary to establish that personal damage was a result of the vaccination and that the case circumstances reveal that adjudication of compensation is required for equity reasons. Judicature concerning the issues reveals that the injured party has a problem with demonstrating the premises.

Keywords: liability for faultless effects of obligatory vaccinations, the equity reasons 